OPEN ACCESS

Edited by:

Ozgur Mete,

University Health Network (UHN),

Canada

Reviewed by:

Jeffrey A. Knauf,

Cleveland Clinic, United States

Chan Kwon Jung,

The Catholic University of Korea,

South Korea

*Correspondence:

Valdemar Máximo

vmaximo@ipatimup.pt

${ }^{\text {t}}$ These authors have contributed equally to this work

Specialty section: This article was submitted to

Thyroid Endocrinology,

a section of the journal

Frontiers in Endocrinology

Received: 01 March 2021

Accepted: 03 May 2021

Published: 24 May 2021

Citation:

Canberk S, Lima AR, Pinto $M$ Soares $P$ and Máximo V (2021)

Epigenomics in Hurthle Cell

Neoplasms: Filling in the Gaps

Towards Clinical Application.

Front. Endocrinol. 12:674666. doi: 10.3389/fendo.2021.674666

\section{Epigenomics in Hurthle Cell Neoplasms: Filling in the Gaps Towards Clinical Application}

\author{
Sule Canberk ${ }^{1,2,3 \dagger}$, Ana Rita Lima ${ }^{1,2,4 \dagger}$, Mafalda Pinto ${ }^{1,2}$, Paula Soares ${ }^{1,2,4,5}$ \\ and Valdemar Máximo ${ }^{1,2,4,5^{*}}$ \\ 1 Instituto de Investigação e Inovação em Saúde (i3S), University of Porto, Porto, Portugal, 2 Cancer Signaling and \\ Metabolism Group, Institute of Molecular Pathology and Immunology of the University of Porto (Ipatimup), Porto, Portugal, \\ ${ }^{3}$ Abel Salazar Institute of Biomedical Sciences (ICBAS), University of Porto, Porto, Portugal, 4 Faculty of Medicine, University \\ of Porto (FMUP), Porto, Portugal, ${ }^{5}$ Department of Pathology, Faculty of Medicine, University of Porto, Porto, Portugal
}

It has been widely described that cancer genomes have frequent alterations to the epigenome, including epigenetic silencing of various tumor suppressor genes with functions in almost all cancer-relevant signalling pathways, such as apoptosis, cell proliferation, cell migration and DNA repair. Epigenetic alterations comprise DNA methylation, histone modification, and microRNAs dysregulated expression and they play a significant role in the differentiation and proliferation properties of TC. In this review, our group assessed the published evidence on the tumorigenic role of epigenomics in Hurthle cell neoplasms $(\mathrm{HCN})$, highlighting the yet limited, heteregeneous and nonvalidated data preventing its current use in clinical practice, despite the well developed assessment techniques available. The identified evidence gaps call for a joint endeavour by the medical community towards a deeper and more systematic study of HCN, aiming at defining epigenetic markers in early diagnose, allowing for accurate stratification of maligancy and disease risk and for effective systemic treatment.

Keywords: thyroid tumors, Hürthle cells, oncocytic cells, mitochondria, epigenomics, epigenetics analysis, Hürthle cell tumors, Hürthle cell carcinoma

\section{INTRODUCTION}

\section{What are Hürthle Cell Tumors?}

Only a few neoplasms have been gaining so many names in their history as oncocytic thyroid neoplasms, reflecting the uncertainty about their nature: Askanazy cell tumor, oxyphilic cell tumor, Langhan's Struma, Baber cell tumor, Getzowa's Struma, Hürthle cell tumor, oncocytic cell tumor, among others (1). In 2004, the $3^{\text {th }}$ edition of the World Health Organization (WHO) Classification of Tumors endorsed the term "oncocytic tumors", instead of "Hürthle cell tumors", to clarify that $75 \%$ of oncocytes were classified as a variant under the category of papillary thyroid carcinoma (PTC) and follicular thyroid carcinoma (FTC) (2). The $4^{\text {th }}$ edition of the WHO Classification of Tumors establishes a new tumor entity under the title of Hürthle cell neoplasms (HCN) (3). The unifying feature in those tumors is the cytoplasmatic enrichement in mithocondria (from several hundreds to thousands), that gives the characteristic acidophilic, granular aspect to oncocytes. 
Hürthle cell neoplasms (HCN) are rare in comparison with non-oncocytic follicular cell-derived neoplasms, with variable incidence and prevalence in different studies. According to the $4^{\text {th }}$ edition of the WHO Classification of Tumors (3), there are two types of HCN: Hürthle cell adenoma (HCA) and Hurthel cell carcinoma (HCA), both composed by $75 \%$ or more of Hürthle cells (2). The presence or absence of invasion into the tumor capsule and vessel (angio) distinguishes HCA from HCC. Similar to FTCs, HCCs are classified as minimally invasive, encapsulated angioinvasive and widely invasive (2).

HCCs are referred to as poorly radioiodine avid and poorly responsive to chemotherapy and radiation. Outcomes of patients with widely invasive HCC are poorer compared with patients with minimally invasive HCC (3-6). Despite their unique morphology and molecular background, no well-defined molecular markers exist in daily practice for HCC. This becomes more of an unmet need not only in the diagnose, but also for the treatment of these tumors. Indeed, HCC corresponds to $3 \%$ to $7 \%$ of all differentiated thyroid cancers, but ranges from $10.5 \%$ to $43 \%$ in recurrent cases, which highlights the unmet need for effective treatment strategies (4-7).

\section{What Is Epigenetics?}

Epigenetics means "beyond genetics," and it represents diverse mechanisms that modify both gene expression and genome stability without affecting the DNA sequence itself. The term "epigenetics" was first coined by Waddington in the early 1940s (8). He described the term as "the causal interactions between genes and their products, which bring the phenotype into being" (8). After many advances achieved over decades, this eloquent description still faithfully describes the main characteristic of epigenetics: phenotype changes in gene expression, which are not related with changes in the DNA sequence both in mitosis and between generations. The effects of epigenetical mechanisms on DNA are not "additional" or "contrary" to genetical mechanisms, but are manifested by an interplay between genetic and epigenetic mechanisms on the roadmap to cancer transformation.

Gene transcription strongly depends on the chromatin structure: in general, the "switch on" or open/decondensed (euchromatin) states are transcriptionally active, whereas the "switch off" or close/condensed (heterochromatin) states are transcriptionally inactive. This continuous interaction between the chromatin remodelling processes is currently denominated "epigenome" - the epigenetic status that determines the way a single eukaryotic genome may manifest it-self in different cell types and developmental stages and which, if aberrant, give rise to cancer and other diseases (9). These conformational changes of epigenetic regulation that may cause mitotically and/or meiotically heritable changes in gene function, without entailing any change in DNA sequence, can be classified into three distinct types: DNA methylation, histone modifications, and non-coding ribosomal RNAs (rRNAs) (Figure 1) (9-11). Each of these epigenetic pathways involve enzymes that transfer the modification ('writers'), enzymes that modify or revert a modification ('erasers'), and enzymes that mediate the interactions of proteins or protein complexes with the modification ('readers') (12). It is well-known that cancer genomes show frequent alterations of the epigenome, including epigenetic silencing of various tumor suppressor genes with functions in almost all cancer-relevant signalling pathways, such as apoptosis, cell proliferation, cell migration and DNA repair (12).

Epigenetic alterations also play a highly significant role in the differentiation and proliferation properties of thyroid carcinoma (TC) $(11,12)$. In this review, our group covers the role of epigenomics in the $\mathrm{HCN}$, along with the main epigenetic mechanisms and potential therapy application of epigenetic targeted therapies in HCC.

\section{Molecular Techniques for the Analysis of Epigenetic Alterations}

Epigenetic alterations, such as DNA methylation and histone modification, as well as microRNAs dysregulated expression, may serve as biomarkers for early detection, disease classification and risk stratification, as well as targets for therapy and chemoprevention.

Numerous techniques have been developed to explore the epigenetic processes, not only at gene level but also genome-wide. Those techniques are widely applied to pathology samples, such as formalin-fixed paraffin-embedded (FFPE) tissues or cytology samples, out of which bisulfite modification of DNA and chromatin immunoprecipitation outline the basis for tracking DNA methylation changes and chromatin modifications, respectively. For microRNA expression alterations, quantitative reverse transcription polymerase chain reaction (qRT-PCR) is normally the elected technique (Figure 2).

\section{DNA Methylation in Hürthle Cell Tumors}

CpG islands are short stretches of DNA encompassing high GC content and CpG dinucleotides (cytosine $5^{\prime}$ to a guanine, separated by a phosphodiester bond) in comparison with the rest of the genome. $\mathrm{CpG}$ islands account for about $1-2 \%$ of the genome and are usually located in the $5^{\prime}$ regulatory region of genes. CpG nucleotides are detected in a lower than expected proportion based on the $\mathrm{G} / \mathrm{C}$ content, and are not homogenously distributed throughout the human genome. $\mathrm{CpG}$ islands are regions of human genome rich in GC content that include the promoters of $60 \%$ of protein coding genes. In humans, DNA methylation occurs most often in CpG islands, and is frequently localized close to promoters of housekeeping genes and in up to $40 \%$ of tissue specific genes $(13,14)$. In general, methylated CpG islands have been correlated with the transcriptional silencing of the associated genes and non-coding genomic regions, although there are exceptions. Thus, DNA methylation is frequently known as a major repressive epigenetic mark. Nevertheless, DNA methylation function varies with the genomic context $(15,16)$. If DNA methylation takes place in proximal and distal regulatory elements (i.e., promoters and enhancers, respectively), it represses transcription by affecting the binding of transcription factors and/or recruiting enzymes that modify chromatin structure. However, DNA methylation of the gene body may enhance transcriptional elongation and affect splicing. Therefore, DNA methylation is a key player in the regulation of gene expression, and it has been implicated in many cellular 

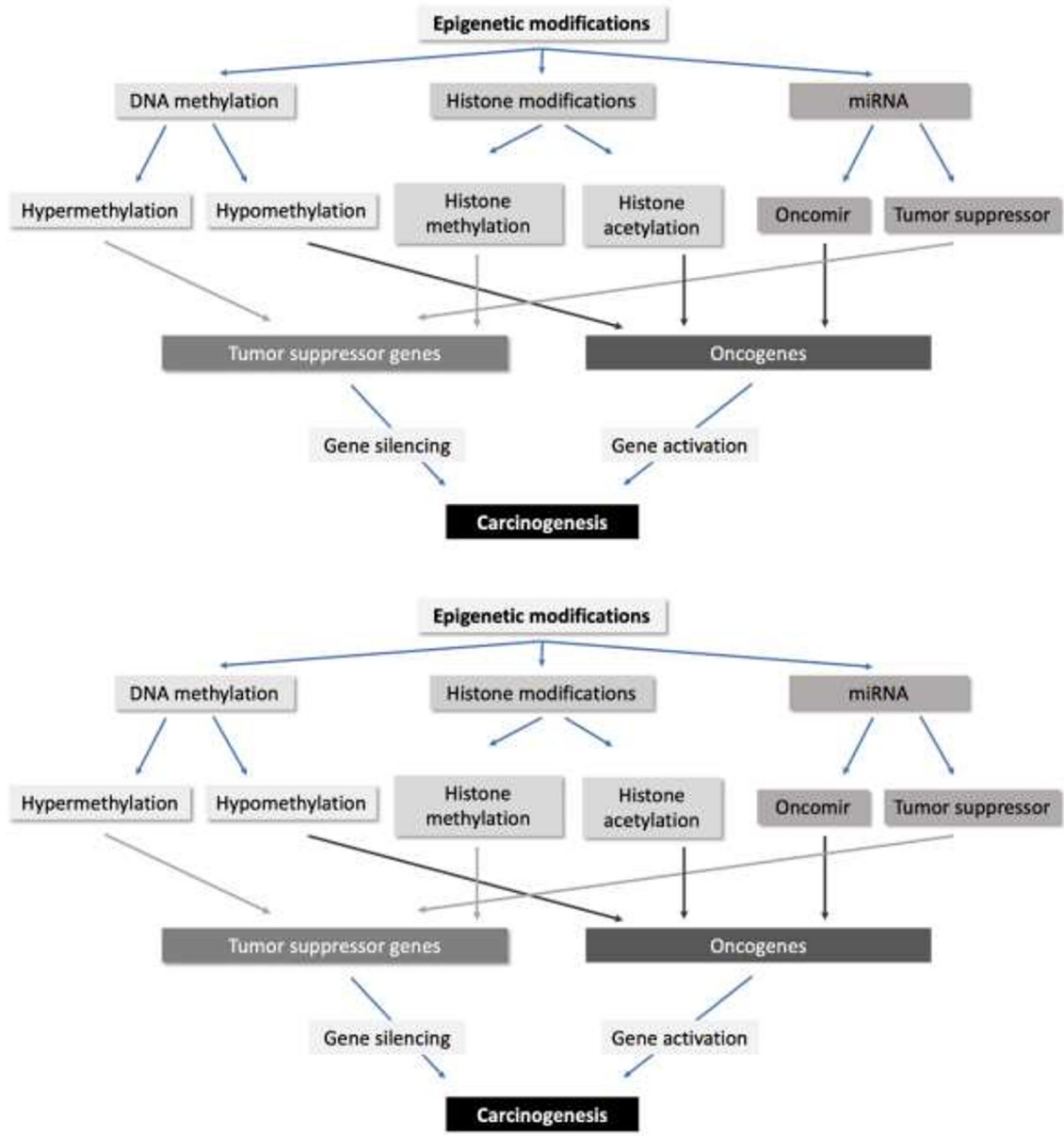

FIGURE 1 | Overview of the epigenetic modifications in human cells and their influences in carcinogenesis.

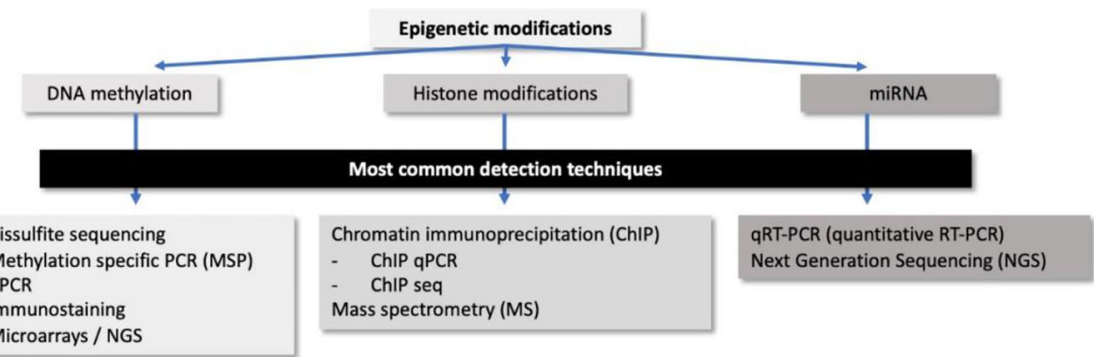

FIGURE 2 | Summary of the most common detection techniques for epigenetic modifications and microRNAs expression used in pathology.

processes, such as imprinting $(17,18)$, X-chromosome inactivation (19), and the establishment and maintenance of cell type-specific expression programs. In other words, the hypermethylation of the $\mathrm{CpG}$ islands in promoter regions, which has been commonly detected in cancer cells, usually leads to the silencing of tumor suppressor genes, whereas the global hypomethylation of DNA has been more frequently reported in association with tumor progression. This pattern of global hypomethylation and regional hypermethylation, might play a pivotal role in human carcinogenesis (20).

DNA methylation is catalysed by a family of DNA methyltransferases (DNMTs) that transfer a methyl group 
from S-adenyl methionine (SAM) to the fifth carbon of a cytosine residue to form $5 \mathrm{mC}$; DNMT1 maintains the DNA methylation pattern from the parental DNA strand in the newly synthesized daughter and is capable of repairing DNA methylation, whereas DNMT3a and DNMT3b can harbor a new methylation pattern without requiring hemi-methylated DNA, thus naming this process as "de novo" DNMT. These two types of methylation patterns are known as "active" and "de novo", respectively, and both contribute to the (im)balance of the roadmap which may lead to tumorigenesis (21). Cancer genome is typically characterized by global hypomethylation concomitantly with hypermethylation of $\mathrm{CpG}$ islands in the promoters of genes that play important roles in regulating cell cycle, apoptosis, differentiation, and cell adhesion (9).

Nowadays, DNA methylation has been gaining attraction for its important wellspring of promising cell-type specific cancer biomarkers, especially since there is yearslong protecting stability of DNA methylation, even in formalin-fixed samples, which makes it easily detectable by well-established techniques (Figure 1), including in cytology materials (14).

There has been a limited number of DNA methylation studies of TC in the literature, and most of them were focused on PTC. The Cancer Genoma Atlas (TCGA) analysed the methylation profiles of 496 cases of TC using a high-density platform (Illumina Infinium HM 450 array), and suggested a classification based on the genomic profiles, which would support a rational patient disease management $(20,22)$. However, when it comes to HCN, the literature available is even more limited (Table 1). One explanation for this is that these neoplasms were classified as a variant of FTA/FTC and many of the studies were designed before the $4^{\text {th }}$ edition of the WHO Classification of Tumors. Also, it is possible that the fact that no differences on the global methylation of cytosine were found between HA and FTA by Galusca et al. (23) led to a lack of interest in new studies in this field. Galusca et al. designed a study based on immunohistochemistry of benign and malignant thyroid neoplasms including ten Hürthle cell adenomas (HA) (23). The authors concluded that benign tumors (FA or HA and MNG) had a significant higher global DNA methylation level than the studied TC cases $(\mathrm{P}<0.001)(23)$. The analyses of benign lesions (hyperplasia, FA and HA) did not find differences between benign lesions and normal thyroid tissues. These results are in line with those previously published concerning 5methylcytidine level in lung cancers cells $(31,32)$, breast carcinoma (33) or colorectal adenocarcinomas (34) where no differences where found in relation to the surrounding normal tissues (35).

One of the recent studies by Park et al. (24), which was designed after the $4^{\text {th }}$ edition of the WHO Classification of Tumors (3), quantitatively profiled the genome-wide DNA methylation in a group of thyroid tumors by means of the Illumina HumanMethylation EPIC bead array. Using a cohort encompassing $24 \mathrm{HA}$ and 5 HCC alongside with PTC, FTC and non-invasive follicular thyroid neoplasm with papillary-like nuclear features (NIFTP) cases, the authors verified a statistically significant hypomethylation of three specific marks
- cg10705422, cg17707274, and cg26849382 - in malignant tumors. They also found that in this tumor group the three marks were significantly associated with recurrent or persistent disease. The authors concluded that DNA methylation levels of those three markers could be a promising novel diagnostic/ prognostic biomarker for well-differentiated thyroid cancer (WDTC). Considering that alterations in DNA methylation play a role in tumorigenesis and disease progression, these DNA methylation markers may be clinically useful for stratifying thyroid tumors in a more efficient way (24).

Brait et al. (25) also evaluated BRAF mutation and promoter DNA methylation for 22 selected cancer-related genes, in a group of thyroid malignant and benign cases, including $12 \mathrm{HA}$ and $2 \mathrm{HCC}$, in comparison with adjacent normal thyroid. The relevance of the upregulation of the $\mathrm{RAF} / \mathrm{MEK} / \mathrm{MAPK}$ kinase pathway in TC, either by a $B R A F$ activating mutation or RASSF1A methylation (hypermethylation mutually exclusive with $B R A F$ mutation) silencing, was further confirmed by this study, without any difference between Hürthle and non-Hürthle morphology. Previously, hypermethylation of tumor supresor gene RASSF1A was reported in 75\% (9 of 12) of FTCs, as well as in a smaller percentage of benign adenomas (44\%), and PTCs (20\%) (36), indicating that this may represent an early step in follicular cell-derived thyroid tumorigenesis. Following this hypothesis, Stephen et al. (26) examined the promoter hypermethylation of 24 tumor suppressor genes using the methylation-specific multiplex ligation-dependent probe amplification (MS-MLPA) assay, as well as that of Na-I symporter (NIS) gene using methylation-specific PCR (MSP). In a pilot study of 21 thyroid cases, including normal thyroid tissue and benign thyroid lesions, PTC and anaplastic thyroid carcinoma (ATC), 2 cases of FTC (one of them formarly named as an oncocytic variant of FTC, now known as HCC). They have concluded that RASSF1, CASP 8 and NIS were frequently methylated in their promoters, which may indicate a role in early tumorigenesis, regardless of the cell type (26).

In 2015, again Stephen et al. (27) analysed retrospectively the promoter methylation status in a cohort of $26 \mathrm{HCC}$ and 27 FTCnbsp;cases, both in comparison with each other and with their adjacent normal tissues. The group found that RASSF1 demonstrates a significant differential methylation between FTCClassic and FTC-Hurthle, with higher methylation levels in FTCClassic $(P<0.001)$, suggesting its use as a molecular marker to differentiate these two subtypes. Comparisons with their matching adjacent normal tissues were also significant $(P=0.01)(26)$.

Bisarro Dos Reis et al. (28) performed an unsupervised clustering analysis of the genome-wide DNA methylation profiles in a series of thyroid tumors. Although HCCs were not separated from FTCs, the FTC/HCC group clustered together with the ATC/ poorly differentiated thyroid carcinoma (PDTC) group and with lymphocytic thyroiditis. This cluster showed major alterations in genes related to immune response. Of note, the FTC/HCC group showed hypermethylation in approximately $3 / 4$ of all identified probes differentially methylated (28).

Ganly et al. (29) recently found that mutations in genes encoding for chromatin and DNA modifying enzymes are 
TABLE 1 | Summary of the main DNA methylation and Histone modifications changes reported in Hürthle cell neoplasms (HCN).

\begin{tabular}{|c|c|c|c|c|}
\hline & Sample size & Molecular aterations & Methods & Reference \\
\hline \multirow[t]{19}{*}{$\begin{array}{l}\text { DNA } \\
\text { methylation }\end{array}$} & $16 \mathrm{FA}$ & $\begin{array}{l}\text { Lower level of } 5 \text {-mC immunostaining in } \mathrm{TC} \text { versus benign tumors or } \\
\text { adjacent normal thyroid parenchyma }(P<0.0001)\end{array}$ & Immunohistochemistry & Galusca et al. (23) \\
\hline & $\begin{array}{l}10 \text { HA, } \\
19 \text { MNG, } \\
17 \text { PTC, } \\
6 \text { FTC }\end{array}$ & & & \\
\hline & $\begin{array}{l}61 \mathrm{FA}, \\
24 \mathrm{HA}, \\
56 \text { NIFTP, } \\
120 \text { PTC, } \\
27 \text { FTC, } \\
5 \text { HCC }\end{array}$ & $\begin{array}{l}\text { Hypomethylation of cg10705422, cg17707274, and cg26849382 } \\
\text { differentiated nonmalignant (FA, HA, and NIFTP) tumors from } \\
\text { differentiated TC }\end{array}$ & $\begin{array}{l}\text { Illumina HumanMethylation EPIC bead } \\
\text { array and pyrosequencing }\end{array}$ & Park et al. (24) \\
\hline & $\begin{array}{l}6 \mathrm{HN} \\
12 \mathrm{FA} \\
6 \mathrm{AN} \\
1 \mathrm{AH}\end{array}$ & $\begin{array}{l}\text { Increased KIF1A probability of methylation in tumor samples ( } 14 \% \text { in } \\
\text { cancer tissue versus } 0 \% \text { in normal and benign; } P=0.02) \\
\text { Increased } R A S S F 1 A \text { methylation levels in cancer versus benign samples } \\
\text { samples }(P=0.05)\end{array}$ & $\begin{array}{l}\text { Quantitative methylation specific PCR } \\
\text { (QMSP) }\end{array}$ & Brait et al. (25) \\
\hline & $\begin{array}{l}6 \text { MNG, } \\
1 \text { multinodular } \\
\text { hyperplasia, } \\
12 \mathrm{HA} \text {, }\end{array}$ & $\begin{array}{l}\text { Negative univariate correlation between BRAF mutation and RASSF1A } \\
\text { methylation }(P=0.035)\end{array}$ & & \\
\hline & $\begin{array}{l}27 \text { PTC, } \\
7 \text { FTC, }\end{array}$ & & & \\
\hline & $\begin{array}{l}2 \mathrm{HCC} \\
8 \mathrm{MTC}\end{array}$ & $\begin{array}{l}\text { Positive univariate correlation between BRAF mutation and methylation } \\
\text { of } R A R \beta 2(P=0.05), T I M P 3(P=0.05) \text { and } D C C(P=0.01)\end{array}$ & & \\
\hline & 5 NTS & CASP8, RASSF1 and NIS methylated in: & & Stephen et al. (26) \\
\hline & $\begin{array}{l}3 \\
\text { hyperfunctioning } \\
\text { nodules }\end{array}$ & - 5/5, 4/5 and 1/5, respectively, in normal thyroid samples & $\begin{array}{l}\text { Methylation specific multiplex ligation- } \\
\text { dependent probe amplification (MS- } \\
\text { MLPA) assay for } 24 \text { tumor suppressor }\end{array}$ & \\
\hline & 11 PTC & - $3 / 3,2 / 3$ and $1 / 3$, respectively, in hyperthyroid samples & genes and methylation-specific PCR & \\
\hline & 1 FTC & - 9/13, 10/13, and 7/13 respectively, in TC & (MSP) for NIS gene & \\
\hline & $1 \mathrm{HCC}$ & $\begin{array}{l}\text { - 3/11, 4/11 and 3/11, respectively, TC cases matched with normal } \\
\text { thyroid tissue } \\
\text { RASSF1 differentially highly methylated in classic FTC versus HCC } \\
(P<0.001)\end{array}$ & & \\
\hline & $\begin{array}{l}27 \text { FTC, } \\
26 \text { HCC }\end{array}$ & $\begin{array}{l}\text { RASSF1 differentially highly methylated in classic } F T C \text { versus normal } \\
\text { adjacent tissue }(P=0.001) \\
\text { Extra-thyroidal extension associated with DAPK1 }(P=0.014) \text { and ESR1 } \\
(P=0.036) \text { methylation; late-stage disease associated with methylation } \\
\text { of DAPK1 }(P=0.034) \text { and ESR1 }(P=0.035)\end{array}$ & $\begin{array}{l}\text { Bisulfite Modification and Quantitative } \\
\text { MSP }\end{array}$ & Stephen et al. (27) \\
\hline & 50 NTS, & $\begin{array}{l}\text { Cluster 1: enriched with FAs, nodular goiters, and minimally invasive } \\
\text { FTCs, showing more frequent hypermethylation events; enriched by } \\
\text { signal transduction-related genes }\end{array}$ & $\begin{array}{l}\text { Genome-wide DNA methylation assay } \\
\text { (450k platform, Illumina) followed by } \\
\text { unsupervised hierarchical clustering } \\
\text { analysis }\end{array}$ & $\begin{array}{l}\text { Bisarro Dos Reis } \\
\text { et al. (28) }\end{array}$ \\
\hline & $\begin{array}{l}17 \text { benign } \\
\text { thyroid lesions, }\end{array}$ & Cluster 2: all normal thyroid tissue samples & & \\
\hline & 60 PTC, & $\begin{array}{l}\text { Cluster 3: exclusively PTC samples, with evident methylation loss; } \\
\text { enriched by signal transduction-related genes }\end{array}$ & & \\
\hline & 8 FTC, & $\begin{array}{l}\text { Cluster 4: all ATC/PDTC, lymphocytic chronic thyroiditis, and remaining } \\
\text { FTC/HCC (most extensively, enriched by alterations involved in immune } \\
\text { response invasive) }\end{array}$ & & \\
\hline & $\begin{array}{l}2 \text { HCC, } \\
1 \text { PDTC, } \\
3 \text { ATC }\end{array}$ & & & \\
\hline & & $\begin{array}{l}\text { Benign thyroid lesions and FTC with greater number of methylated CpG } \\
\text { in comparison with normal thyroid tissue; hypomethylation predominant } \\
\text { in PTC and PDTC } \\
\text { FTC/HCC with hypermethylation in } \sim 3 / 4 \text { of all identified probes } \\
\text { differentially methylated }\end{array}$ & & \\
\hline
\end{tabular}


TABLE 1 | Continued

\begin{tabular}{|c|c|c|c|c|}
\hline & Sample size & Molecular aterations & Methods & Reference \\
\hline & $56 \mathrm{HCC}$ & $\begin{array}{l}\text { Mutations in 59\% of tumors [33/56]: } \\
\text { A. Chromatin-modifying complexes } \\
\text { - SWI/SNF, ISWI/CHD, and INO80 families - ARID1A (4\%), CHD2, 4, 5, } \\
\text { 8, 9, and H (12\%) } \\
\text { - Histone acetyltransferase (CREBBP [5\%] and BRD7 [7\%]) } \\
\text { - Histone methyltransferases (KMT2C [5\%], NSD1 [4\%], and EZH1 [4\%]) } \\
\text { - Histone deacetylases (HA T7 [2\%] and SIRT6 [2\%]) } \\
\text { - Histone demethylases (PHF2 [4\%] and KDM2B, 4C, and 5C [6\%]) } \\
\text { - Histones (HIST1H1E [2\%] and HIST1H3D [2\%]) } \\
\text { B. DNA modifiers (9\% [6/56 tumors]): } \\
\text { - DNMT1 [2\%] and DNMT3A [2\%]) } \\
\text { - DNA demethylases (TET1 [2\%] and TET2 [5\%]) } \\
\text { ARHI underexpression in FTC, including six oFTC versus FAs, }(P= \\
\text { 0.0018) }\end{array}$ & Whole exome sequencing (WES) & Ganly et al. (29) \\
\hline & $\begin{array}{l}5 \text { NTS, } \\
14 \text { FA, } \\
11 \text { FTC, } \\
6 \text { HCC, } \\
7 \text { PTC }\end{array}$ & $\begin{array}{l}A R H I \text { underexpression in all minimally invasive FTC }(2 \text { classic FTC and } 2 \\
\text { HCC }) \\
\text { ARHI underexpression in FTC versus normal thyroid tissue }(P=0.022) \\
\text { or FAs }(P=0.0091) \\
A R H I \text { underexpression in FTC versus PTC }(P=0.022)\end{array}$ & $\begin{array}{l}\text { Real-time quantitative polymerase } \\
\text { chain reaction (RT-PCR) } \\
\text { Sodium bisulfite genomic sequencing } \\
\text { Quantitative PCR (qPCR) }\end{array}$ & Weber et al. (30) \\
\hline $\begin{array}{l}\text { Histone } \\
\text { modifications }\end{array}$ & $56 \mathrm{HCC}$ & $\begin{array}{l}\text { Mutations in histone acetyltransferases (CREBBP [5\%] and BRD7 [7\%]), } \\
\text { histone methyltransferases (KMT2C [5\%], NSD1 [4\%], and EZH1 [4\%]), } \\
\text { histone deacetylases (HAT7 [2\%] and SIRT6 [2\%]), histone } \\
\text { demethylases (PHF2 [4\%] and KDM2B, 4C, and 5C [6\%]), and histones } \\
\text { (HIST1H1E [2\%] and HIST1H3D [2\%]) }\end{array}$ & Whole exome sequencing (WES) & Ganly et al. (29) \\
\hline
\end{tabular}

FA, follicular adenoma; HA, Hürthle cell adenoma; MNG, multinodular goiter; PTC, papillary thyroid carcinoma; FTC, follicular thyroid carcinoma; NIFTP, non-invasive follicular thyroid neoplasm with papillary-like nuclear features; HCC, Hürthle cell carcinoma; HN, hyperplastic nodule; NTS, normal thyroid specimens; AH, adenomatoid hyperplasia; MTC, medullary thyroid carcinoma; PDTC, poorly differentiated thyroid carcinoma; ATC, anaplastic thyroid carcinoma; ofTC, oncocytic variant of follicular thyroid carcinoma.

frequent, with $59 \%$ of the 56 studied HCC cases harbouring such mutations.

Finally, it is noteworthy the contribution of Weber et al. (30) for the understanding of the carcinogenesis of FTC when they showed that the tumor suppressor gene aplaysia ras homolog I $(A R H I)$ was frequently underexpressed in FTCs, even in minimally invasive tumors, including 6 oncocytic variants $(P=0.0018)$, as compared to PTC or FA. Based on their their studies, the authors have suggested that silencing of the putative maternally imprinted tumor suppressor gene $A R H I$, primarily by large genomic deletion associated with hypermethylation of the genomically imprinted allele, is an important event in follicular thyroid carcinogenesis.

\section{Histone Modification in Hürthle Cell Tumors}

DNA is associated with histone proteins to form a condensed structure known as chromatin. Chromatin encompasses $147 \mathrm{bp}$ of DNA bundling up an octamer of four histone proteins $(\mathrm{H} 2 \mathrm{~A}$, $\mathrm{H} 2 \mathrm{~B}, \mathrm{H} 3$, and H4) (37). Histone modifications can go through various types of post-translational changes, including methylation, acetylation, phosphorylation and ubiquitination, and these may modulate gene silencing concomitantly with DNA promoter methylation $(17,38)$. In general, acetylation of histones, such as $\mathrm{H} 3$ and $\mathrm{H} 4$, and methylation of the lysine-4 residue of histone $\mathrm{H} 3$ (H3K4) are associated with transcriptional activation and active genes $(39,40)$. Deacetylation, on the other hand, is associated with gene silencing of tumor suppressor genes in the carcinogenesis process $(40,41)$. Methylated DNA recruits methylbinding proteins (MBDPs), which have methyl-CpG-binding domains (MBD), to hypermethylated DNA. MBDPs associate with histone deacetylases, resulting in chromatin remodeling and gene silencing. In addition to these mechanisms of silencing, histone methyltransferase (HMTs) repress transcription by methylation of lysine 9 of histone 3 (H3K9) or lysine 27 of histone 3 (H3K27) (40). Fewer studies have been published on the histone modifications in thyroid neoplasms (Table 1). Puppin et al. (42) reported changes in the overall histone acetylation levels in TC, with lower levels of acetylated $\mathrm{H} 3$ at $\mathrm{K} 18$ residue in undifferentiated cancers in comparison with differentiated types of cancers. Of interest, based on a study that was carried out on the human TC-derived cell lines TPC-1, KTC-1, NPA, WRO, ARO, DRO, 8505C, 8303C, the CpG promoter region of the thyroid transcription factor-1 (TTF-1), an essential gene for thyroid organogenesis governing thyroid functions by regulating the expression of thyroid-specific genes including thyroglobulin $(T G)$, thyroid peroxidase (TPO), thyroidstimulating hormone receptor (TSHR) and NIS, was found to be hypermethylated in those differentiated and undifferentiated TC cell lines, along with a reduction in acetyl-H3-K9 and an increase in dimethyl-H3-K9 in cells seen in a subset that lost TTF-1 expression (43). As mentioned before, epigenetic modification mutations have been identified as common events in genes of HCC encoding chromatin or DNA modifiers, but mutations were also detected in histone acetyltransferases (CREBBP [5\%] and BRD7 [7\%]), histone methyltransferases (KMT2C [5\%], NSD1 [4\%], and EZH1 [4\%]), histone deacetylases (HAT7 [2\%] and SIRT6 [2\%]), histone 
demethylases (PHF2 [4\%] and KDM2B, 4C, and 5C [6\%]), and histones (HIST1H1E [2\%] and HIST1H3D [2\%]) (29).

\section{RNA-Associated Silencing in Hürthle Cell Tumors}

MicroRNAs (mi-RNAs) are small $(19-23,31,32)$ non-coding RNAs, which control gene expression through posttranscriptional regulation of various cellular processes, such as differentiation, proliferation and apoptosis (44). Signatures associated with their expression have been related to diagnosis, staging, prognosis, and response to treatment in human tumors (45-47). Changes in mi-RNA expression are involved in carcinogenesis and tumor progression, through downregulation of tumor suppressor genes and/or upregulation of oncogene (4851). One of the first pivotal series which characterized the miRNA expression profile of different benign and malignant thyroid neoplasms, including HA and HCC, was published by Nikiforov et al. (52). The ten most up-regulated miRNAs in HA when compared with normal thyroid tissue were, respectively from higher to lower, miR-31, miR-339, miR-183, miR-182, miR-181b, miR-221, miR-96, miR-182, miR-224 and miR-203. In comparison with thyroid hyperplastic tissue, miR-31, miR339, miR-183, miR-221 and miR-203 were significantly more expressed in HA. In HCC, the ten most up-regulated miRNAs were miR-187, miR-221, miR-339, miR-183, miR-222, miR181b, miR-182, miR-213, miR-96, miR-197, respectively from higher to lower levels. miR-187, miR-221, miR-339, miR-183, miR-222, and the miR-197 were significantly more expressed when compared with hyperplastic thyroid tissue. Interestingly, within the adenoma group, non-oncocytic tumors expressed a pattern of miRNA different from that of HA. Indeed, miR-200a was the most expressed miRNA in HA and miR-31 was the most expressed in HCC. A cluster analysis showed that clusters of miRNA expression in HCN are different from those of nononcocytic tumors, which supports the theory that $\mathrm{HCN}$ represent a unique class of thyroid tumors, as opposed to a subgroup of follicular-derived tumors (2). The evidence that a cluster of identical miRNAs is present in both benign and malignant follicular tumors with Hürthle cell characteristics supports the assumption that these represent a phenotype that is superimposed on different oncogenic genotypes (53). Vriens et al. (54) found that four of ten miRNAs, initially mapped by a miRNA array, were significantly and differentially expressed when comparing benign and malignant thyroid neoplasms by real-time quantitative polymerase chain reaction (RT-qPCR). In particular, miR-100, miR-125b, miR-138, and miR-768-3p were found to be overexpressed in malignant follicular tumors and in HCC samples when compared with HA (54). The accuracy for distinguishing benign from malignant $\mathrm{HCN}$ was $98 \%$ (miR-138 and miR-768-3p) (54). Dettmer et al. (55) assessed the difference in miRNA expression between PDTC and WDPTC using PCRMicroarrays. In this study, they found that the oncocytic variant of PDTC (oPDTC) presented an upregulation of miR-221 and miR-885-5p when compared with the non-oPDTC (55). When oPDTC were compared with HCC, there was a loss of expression of miR-125a-5p, -183-3p, -219-5p, -221 and miR-885-5p. In addition, miR-222 was twice more expressed in oPDTC compared with HCC (55). Petric et al. (56) assessed whether there was any miRNA which could be predictive of metastases in HCC, based on a series of 39 patients, and using TaqMan miRNA assays targeting six miRNAs (miR-138, miR-183, miR-221, miR222, miR-768-3p, and miR-885-5p). These authors found that miR-138 and miR-768-3p were significantly downregulated in HCC tumor samples, as well as in patients with metastatic disease, but not in patients with non-metastatic disease, in comparison with normal tissue (56). In tumors of patients without metastases, miR-221 and miR-885-5p were significantly upregulated when compared with normal tissue. When the difference of miRNA expression in tumor versus normal tissue was compared between patients with and without metastases, miR183 , miR-221, and miR885-5p were significantly downregulated in patients with metastases, suggesting that the expression of miR183 , miR-221, and miR-885-5p in tumor tissue is inversely correlated with the risk of distant metastases in patients with HCC (56). A study by Covach et al. (57), which assessed metastases associated lung adenocarcinoma transcript 1 (MALAT1) and miR-RNA-885-5p through in situ hybridization (ISH) found that MALAT1 was more highly expressed in HCCs compared with FTCs, although the differences were not statistically significant $(P=0.06)$. Likewise, miR-885 expressed in similar levels in FTCs and HCCs. Jacques et al. (58) reported the results of transcriptomic analysis, which led to the identification of 13 genes allowing the discrimination between thyroid adenomas, HA/HCC and PTC. The overall miRNA analysis revealed 10 differentially expressed miRNAs, whose levels were confirmed by qPCR (58). In their study, TP53 and RUNX1 were the main genes regulated by the selected miRNAs, which proved to play a role in thyroid tumor development and differentiation. The targeted assay tested by these authors allowed the specific investigation of thyroid mitochondrial metabolism and tumorigenesis genes, which are partially regulated by miRNAs. In this study, mitochondrial metabolism of HA/HCC appeared to differ from that of PTC, suggesting metabolic variations of the organelle in these two tumor types (58) (Table 2).

\section{Hürthle Cell Tumors and Epigenetic Therapy}

Previous studies have suggested that patients with HCC should be treated as non-HCC patients with equivalent tumor staging (59). Specific recommendations for the treatment of HCC are lacking (60), and the management of HCC tends to be similar to that of FTC, acknowledging two particular characteristics: locoregional lymph node and distant metastases are more frequent, and metastatic HCC tend to be less prone to radioiodine-avidity. In general, the HCC clinical management follows the most recent ATA guidelines and National Comprehensive Cancer Network (NCCN) Thyroid Cancer guidelines $(61,62)$. Treatment options for recurrent HCC include radioiodine, radiofrequency ablation, ethanol ablation, external beam radiotherapy, and systemic treatment. Systemic treatment should be considered for patients with radiodinerefractory unresectable persistent, recurrent or metastatic disease. The options include tyrosine kinase inhibitors (TKIs), 
TABLE 2 | Summary of the main RNA-associated silencing changes reported in Hurthle cell neoplasms.

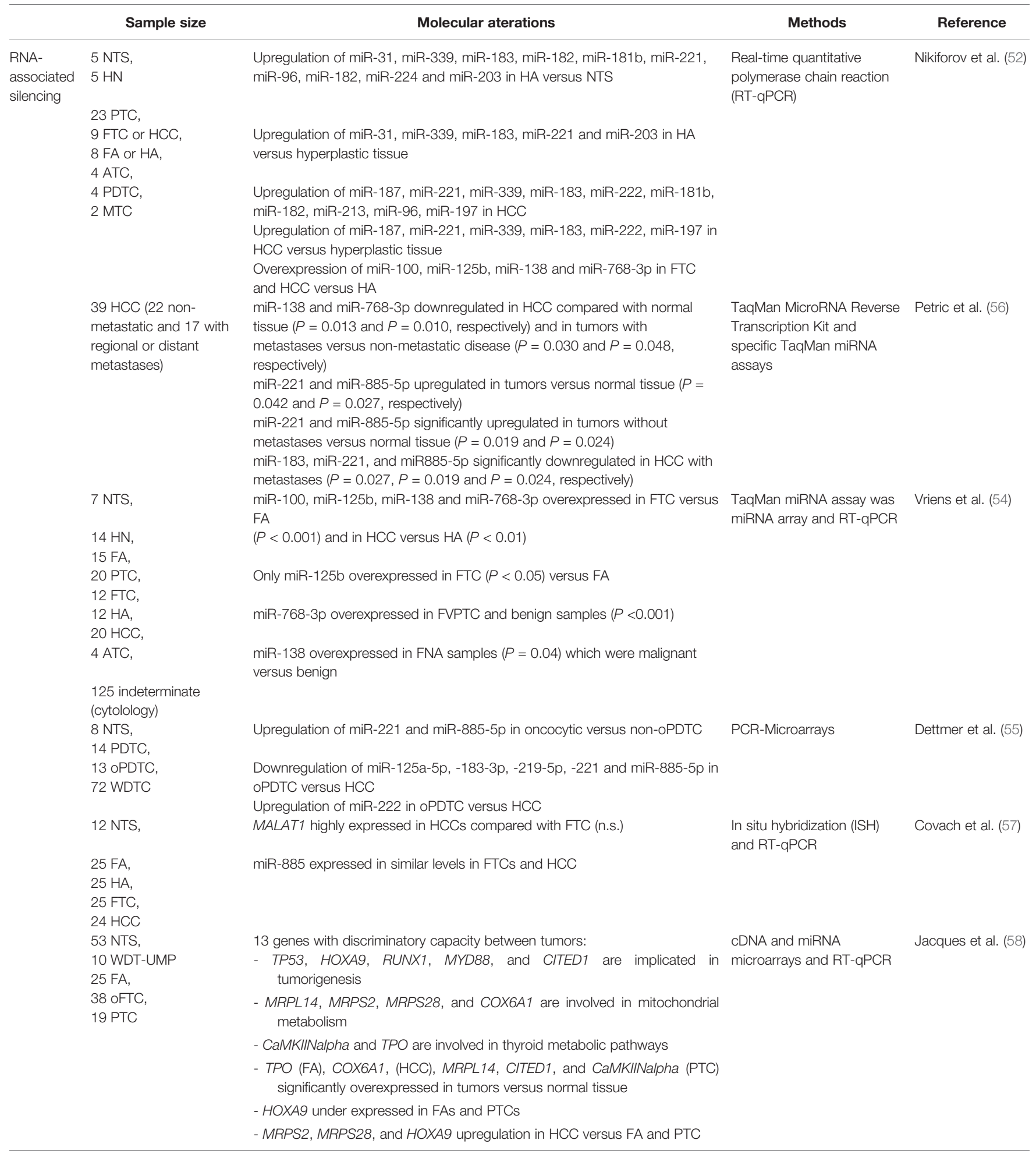

NTS, normal thyroid specimens; HN, hyperplastic nodule; PTC, papillary thyroid carcinoma; FTC, follicular thyroid carcinoma; HCC, Hürthle cell carcinoma; FA, follicular adenoma; HA, Hürthle cell adenoma; ATC, anaplastic thyroid carcinoma; PDTC, poorly differentiated thyroid carcinoma; MTC, medullary thyroid carcinoma; MNG, multinodular goiter; NIFTP, noninvasive follicular thyroid neoplasm with papillary-like nuclear features; OPDTC, oncocytic poorly differentiated thyroid carcinoma; WDT-UMP, well-differentiated tumor of uncertain malignant potential; oFTC, oncocytic variant of follicular thyroid carcinoma. 
such as levantinib and sorafenib, but despite the benefits shown in progression-free survival, they have not shown any improvements in overall survival $(63,64)$.

The promise of epigenetic alterations as therapeutic targets is that, unlike mutations, they can be potentially reverted. Azacitidine and decitabineare cytidine analogues, which inhibit DNA methyltransferase, were first synthesized in the early 1960s and were approved for the treatment of myelodysplastic syndromes. While their demethylating effect depends on incorporation of derived deoxy-azanucleotides into DNA, azacitidine-induced cytotoxicity is mainly due to incorporation into RNA in the cell cycle phase G1 at low drug concentrations, and to the incorporation into both RNA and DNA in the G1 and S phases of the cell cycle (65). Decitabine was shown to cause hypomethylation of DNA and intraS-phase arrest of DNA replication, as its activity is exclusive to the incorporation into DNA of replicating cells (66). A phase 1 trial is currently assessing the ability of azacitidine to restore iodine uptake by dedifferentiated FTC and PTC, enabling detection and treatment with radioiodine in patients with metastatic disease, and will determine the efficacy of azacitidine in combination with radioiodine in this patient population. Interestingly, decitabine was shown to revert the TSH-R and NIS expression in human TC cell lines (67-69), having an inhibitory effect on the growth of undifferentiated TC cells (70). A phase 2 clinical trial assessing the effect of decitabine in patients with stage IV PTC and FTC unresponsive to radioiodine has completed recruitment and results are pending publication.

HDAC inhibitors have been studied in various tumor types and have shown promising results, particularly in hematological malignancies (71). Previous studies have showed that HDAC inhibitors could induce apoptosis and cell cycle arrest in ATC cell lines (72), and that these effects would likely be linked to an increase in the transcription of TP53, as well as to the modulation of cell cycle-related molecules (73-75). In addition, HDAC inhibitors, including depsipeptide and trichostatin, have effects on the reexpression of NIS, TPO and Tg genes, with an increased radioiodine uptake in PDTC and ATC cell lines, in vitro and in vivo $(76,77)$. The TSHR and NIS are key players in radioiodinebased treatment of differentiated thyroid cancers. Agostino et al. (78) performed the analysis of NIS and TSHR genes expression, and of the epigenetic control occurring at the gene promoter level after inhibition of RAS-BRAF-MAPK and PI3K-Akt-mTOR pathways in four human TC cell lines. The authors found that, in TC cells, MEK and Akt signaling pathways control pos-/translational modifications of histones at specific genes, and these changes are noted even before the effects become more obvious in the proliferation rates. Recently, Wächter et al. (79) studied the cytotoxic effects of histone deacetylase inhibitors panobinostat, vorinostat (suberoylanilide hydroxamic acid (SAHA)), and trichostatin A in five TC cell lines, including PTC, FTC and ATC. All three compounds showed cytotoxic effect and a strong reexpression/over-expression of NIS transcript independently of the cell line. This recapitulates part of the results mentioned previously for poorly differentiated and anaplastic tumors (77), and supports the idea that the cell lines expressing low or absent NIS could be the most sensitive to deacetylase inhibitors. NIS expression could be modulated by the expression of miRNAs belonging to Let7 family (80). In the Watcther et al. study (79), treatment with these deacetylase inhibitors led to a stable expression or upregulation of H19, a long non-coding RNA highly expressed during tumorsigenesis in several tumors, including TC (81), in the tested TC cell lines. Interestingly, H19 had been shown to inhibit Insulin Receptor Substrate 1 (IRS-1), reducing cell viability, migration, and invasion in TC (82), which supports the thesis that $\mathrm{H} 19$ may have a tumor suppressor role in TC cells treated with deacetylase inhibitors, leading to differentiation and cell death (79). Finally, deacetylase inhibitors also led to the down-regulation of TTF1 transcripts, a thyroid transcription factor with oncogenic properties, in three cell lines. All these are relevant characteristics of deacetylase inhibitors for which clinical utility in patients with radioiodine refractory TC must be tested in clinical trials. Currently, there are phase 1 and 2 clinical trials using HDAC inhibitors such as romidepsin, belinostat, panobinostat and valproic acid in patients with TC, including limited cases of HCC, but the results are not encouraging (83-87).

Finally, although it is becoming evident that mi-RNAs play a role in the HCC pathogenesis, with an opportunity for a future as diagnose markers, there are still many unanswered questions on how they can contribute to the selective methylation or demethylation of TC genes. In what concerns treatment application, mi-RNAs are still far from being a druggable target, although it is possible that an acceleration of this pathway may be seen in the near future as RNAbased therapies are becoming an area of high investment, such is the case of the recent advances in the prevention area in vaccines. In vitro experiments by Vriens et al. (54), using a FTC cell line with overexpression of miR-100, miR-125b, and miR-138, found that the inhibition of the miRNAs by their targeted anti-mir led to cell growth arrest. On the other hand, the overexpression by pre-miRNAs (pre-miR-100, pre-miR-125b, and pre- miR-138) dramatically increased proliferation. This, and other pre-clinical reports, may pave the way for the next step into clinical trials, which has not yet started. As HCC are known for their mitochondrial DNA mutations and respiratory complex(es) metabolic disfunction, it would be very interesting to explore the potential treatment opportunities oppened by the fact that miRNAs are translocated into mitochondria - thus modifying the expression of the mitochondrial genome. Likewise, the alterations in the mitochondrial DNA, which also contribute to epigenetic modifications of the nuclear DNA (88), could, at least in theory, be tackled in HCC.

\section{CONCLUSIONS}

Since Waddington's introduction of epigenetics in the 1940s, there has been a significant development in the field and its application to cancer. The extension of these advances holds promises in establishing novel diagnostic and prognostic markers, with patient management implications, if not at the level of readily available systemic treatment options, certainly in the surgical and follow-up standards.

However, research on thyroid neoplasms has remained relatively limited by comparison with other cancers. One such case is the $\mathrm{HCN}$, 
which was endorsed by the $4^{\text {th }}$ edition of the WHO Classification of Tumors. As one can see in this review, the evidence pertaining to the epigenomics of $\mathrm{HCN}$ is poor and inconsistent. In addition, a limitation in our review is that different referenced studies have used different morphological criteria to diagnose tumors falling into the spectrum of oncocytic follicular epithelial derived neoplasms, which are not necessarily follicular patternedneoplasms, and therefore some of the epigenomics evidence trends may not always reflect a HCN hystotype. This reinforces the need for determined and focused efforts in research and publication on the topic, taking into consideration the new pathological classification of HCN. Future advances in the research will allow the definition of diagnostic markers as well as specific guidelines towards a more personalized and effective treatment of $\mathrm{HCN}$.

\section{AUTHOR CONTRIBUTIONS}

Conceptualization: SC, AL, VM. Writing - original draft: SC, AL, MP. Writing - review and editing: SC, AL, PS, VM. Supervising: VM. All authors contributed to the article and approved the submitted version.

\section{REFERENCES}

1. Canberk S, Lima AR, Correia M, Batista R, Soares P, Máximo V, et al. Oncocytic Thyroid Neoplasms: From Histology to Molecular Biology. Diagn Histopathol (2019) 25(5):154-65. doi: 10.1016/j.mpdhp.2019.02.002

2. DeLellis RA LR, Heitz PU, Eng C. Who Classification of Tumors. In: Pathology and Genetics of Tumors of Endocrine Organs, Vol. 2004. Lyon: IARC Press (2014)

3. Lloyd RV, Osamura RY, Klöppel G, Rosai J. Who Classification of Tumors of Endocrine Organs, 4th, Vol. 10. Lyon: IARC Press (2017).

4. Goffredo P, Roman SA, Sosa JA. Hurthle Cell Carcinoma. Cancer (2013) 119: (3):504-11. doi: $10.1002 / \mathrm{cncr} .27770$

5. Oluic B, Paunovic I, Loncar Z, Djukic V, Diklic A, Jovanovic M, et al. Survival and Prognostic Factors for Survival, Cancer Specific Survival and Disease Free Interval in 239 Patients With Hurthle Cell Carcinoma: A Single Center Experience. BMC Cancer (2017) 17(1):371. doi: 10.1186/s12885-017-3370-x

6. Petric R, Gazic B, Besic N. Prognostic Factors for Disease-Specific Survival in 108 Patients With Hürthle Cell Thyroid Carcinoma: A Single-Institution Experience. BMC Cancer (2014) 14(1):777. doi: 10.1186/1471-2407-14-777

7. Mills SC, Haq M, Smellie WJB, Harmer C. HRthle Cell Carcinoma of the Thyroid: Retrospective Review of 62 Patients Treated at the Royal Marsden Hospital Between 1946 and 2003. Eur J Surg Oncol (2009) 35(3):230-4. doi: 10.1016/j.ejso.2008.06.007

8. Waddington CH. The Epigenotype. 1942. Int J Epidemiol (2012) 41(1):10-3. doi: $10.1093 /$ ije/dyr184

9. Catalano MG, Fortunati N, Boccuzzi G. Epigenetics Modifications and Therapeutic Prospects in Human Thyroid Cancer. Front Endocrinol (Lausanne) (2012) 3:40. doi: 10.3389/fendo.2012.00040

10. Russo D, Damante G, Puxeddu E, Durante C, Filetti S. Epigenetics of Thyroid Cancer and Novel Therapeutic Targets. J Mol Endocrinol (2011) 46(3):R7381. doi: 10.1530/JME-10-0150

11. Kondo T, Asa SL, Ezzat S. Epigenetic Dysregulation in Thyroid Neoplasia. Endocrinol Metab Clin North Am (2008) 37(2):389-400. ix. doi: 10.1016/ j.ecl.2007.12.002

12. Plass C, Pfister SM, Lindroth AM, Bogatyrova O, Claus R, Lichter P. Mutations in Regulators of the Epigenome and Their Connections to Global Chromatin Patterns in Cancer. Nat Rev Genet (2013) 14(11):765-80. doi: $10.1038 / \operatorname{nrg} 3554$

\section{FUNDING}

This work was financed by FEDER-Fundo Europeu de Desenvolvimento Regional funds through the COMPETE 2020 -Operacional Programme for Competitiveness and Internationalization (POCI), Portugal 2020, and by Portuguese funds through FCT - Fundação para a Ciência e a Tecnologia/ Ministério da Ciência, Tecnologia e Inovação in the framework of the project "Institute for Research and Innovation in Health Sciences" (POCI-01-0145-FEDER-007274). Additional funding by the European Regional Development Fund (ERDF) through the Operational Programme for Competitiveness and Internationalization-COMPETE2020, and Portuguese national funds via FCT, under project POCI-01-0145-FEDER016390: CANCEL STEM and from the FCT under the project POCI-01-0145-FEDER-031438: The other faces of telomerase: Looking beyond tumor immortalization (PDTC/MED_ONC/ 31438/2017). Additional funding through the Sociedade Portuguesa de Endocrinologia, Diabetes e Metabolismo Bolsa Edward Limbert MERCK/SPEDM 2019. SC is supported by FCT in the framework of a $\mathrm{PhD}$ grant $(\mathrm{SFRH} / \mathrm{BD} /$ 147650/2019).

13. Bird AP. DNA Methylation and the Frequency of CpG in Animal DNA Nucleic Acids Res (1980) 8(7):1499-504. doi: 10.1093/nar/8.7.1499

14. Zafon C, Gil J, Perez-Gonzalez B, Jorda M. DNA Methylation in Thyroid Cancer. Endocr Relat Cancer (2019) 26(7):R415-R39. doi: 10.1530/ERC-190093

15. Jones PA. Functions of DNA Methylation: Islands, Start Sites, Gene Bodies and Beyond. Nat Rev Genet (2012) 13(7):484-92. doi: 10.1038/nrg3230

16. Baubec T, Schübeler D. Genomic Patterns and Context Specific Interpretation of DNA Methylation. Curr Opin Genet Dev (2014) 25:85-92. doi: 10.1016/ j.gde.2013.11.015

17. Ting AH, McGarvey KM, Baylin SB. The Cancer Epigenome-Components and Functional Correlates. Genes Dev (2006) 20(23):3215-31. doi: 10.1101/ gad.1464906

18. Swain JL, Stewart TA, Leder P. Parental Legacy Determines Methylation and Expression of an Autosomal Transgene: A Molecular Mechanism for Parental Imprinting. Cell (1987) 50(5):719-27. doi: 10.1016/0092-8674(87)90330-8

19. Mohandas T, Sparkes RS, Shapiro LJ. Reactivation of an Inactive Human $X$ Chromosome: Evidence for X Inactivation by DNA Methylation. Science (1981) 211(4480):393-6. doi: 10.1126/science.6164095

20. Lee JS. Exploring Cancer Genomic Data From the Cancer Genome Atlas Project. BMB Rep (2016) 49(11):607-11. doi: 10.5483/BMBRep.2016.49.11.145

21. Moore LD, Le T, Fan G. Dna Methylation and Its Basic Function. Neuropsychopharmacology (2013) 38(1):23-38. doi: 10.1038/npp.2012.112

22. Cancer Genome Atlas Research N. Integrated Genomic Characterization of Papillary Thyroid Carcinoma. Cell (2014) 159(3):676-90. doi: 10.1016/ j.cell.2014.09.050

23. Galusca B, Dumollard JM, Lassandre S, Niveleau A, Prades JM, Estour B, et al. Global DNA Methylation Evaluation: Potential Complementary Marker in Differential Diagnosis of Thyroid Neoplasia. Virchows Arch (2005) 447(1):1823. doi: 10.1007/s00428-005-1268-5

24. Park JL, Jeon S, Seo EH, Bae DH, Jeong YM, Kim Y, et al. Comprehensive DNA Methylation Profiling Identifies Novel Diagnostic Biomarkers for Thyroid Cancer. Thyroid (2020) 30(2):192-203. doi: 10.1089/thy. 2019.0011

25. Brait M, Loyo M, Rosenbaum E, Ostrow KL, Markova A, Papagerakis S, et al. Correlation Between BRAF Mutation and Promoter Methylation of TIMP3, Rarß2 and RASSF1A in Thyroid Cancer. Epigenetics (2012) 7(7):710-9. doi: 10.4161/epi.20524 
26. Stephen JK, Chitale D, Narra V, Chen KM, Sawhney R, Worsham MJ. DNA Methylation in Thyroid Tumorsigenesis. Cancers (Basel) (2011) 3(2):1732-43. doi: $10.3390 /$ cancers3021732

27. Stephen JK, Chen KM, Merritt J, Chitale D, Divine G, Worsham MJ. Methylation Markers for Early Detection and Differentiation of Follicular Thyroid Cancer Subtypes. Cancer Clin Oncol (2015) 4(2):1-12. doi: 10.5539/ cco.v4n2p1

28. Bisarro Dos Reis M, Barros-Filho MC, Marchi FA, Beltrami CM, Kuasne H, Pinto CAL, et al. Prognostic Classifier Based on Genome-Wide DNA Methylation Profiling in Well-Differentiated Thyroid Tumors. J Clin Endocrinol Metab (2017) 102(11):4089-99. doi: 10.1210/jc.2017-00881

29. Ganly I, Makarov V, Deraje S, Dong Y, Reznik E, Seshan V, et al. Integrated Genomic Analysis of Hurthle Cell Cancer Reveals Oncogenic Drivers, Recurrent Mitochondrial Mutations, and Unique Chromosomal Landscapes. Cancer Cell (2018) 34(2):256-70 e5. doi: 10.1016/j.ccell.2018.07.002

30. Weber F, Aldred MA, Morrison CD, Plass C, Frilling A, Broelsch CE, et al. Silencing of the Maternally Imprinted Tumors Suppressor ARHI Contributes to Follicular Thyroid Carcinogenesis. J Clin Endocrinol Metab (2005) 90 (2):1149-55. doi: 10.1210/jc.2004-1447

31. Piyathilake CJ, Frost AR, Bell WC, Oelschlager D, Weiss H, Johanning GL, et al. Altered Global Methylation of DNA: An Epigenetic Difference in Susceptibility for Lung Cancer Is Associated With Its Progression. Hum Pathol (2001) 32(8):856-62. doi: 10.1053/hupa.2001.26471

32. Piyathilake CJ, Johanning GL, Frost AR, Whiteside MA, Manne U, Grizzle WE, et al. Immunohistochemical Evaluation of Global DNA Methylation: Comparison With In Vitro Radiolabeled Methyl Incorporation Assay. Biotech Histochem (2000) 75(6):251-8. doi: 10.3109/10520290009085128

33. Soares J, Pinto AE, Cunha CV, Andre S, Barao I, Sousa JM, et al. Global DNA Hypomethylation in Breast Carcinoma: Correlation With Prognostic Factors and Tumors Progression. Cancer (1999) 85(1):112-8. doi: 10.1002/(SICI) 1097-0142(19990101)85:1<112::AID-CNCR16>3.0.CO;2-T

34. Hernandez-Blazquez FJ, Habib M, Dumollard JM, Barthelemy C, Benchaib M, de Capoa A, et al. Evaluation of Global DNA Hypomethylation in Human Colon Cancer Tissues by Immunohistochemistry and Image Analysis. Gut (2000) 47(5):689-93. doi: 10.1136/gut.47.5.689

35. Cheng Y, He C, Wang M, Ma X, Mo F, Yang S, et al. Targeting Epigenetic Regulators for Cancer Therapy: Mechanisms and Advances in Clinical Trials. Signal Transd Target Ther (2019) 4:62. doi: 10.1038/s41392-019-0095-0

36. Xing M, Cohen Y, Mambo E, Tallini G, Udelsman R, Ladenson PW, et al. Early Occurrence of RASSF1A Hypermethylation and its Mutual Exclusion With BRAF Mutation in Thyroid Tumorsigenesis. Cancer Res (2004) 64 (5):1664-8. doi: 10.1158/0008-5472.CAN-03-3242

37. Kouzarides T. Chromatin Modifications and Their Function. Cell (2007) 128 (4):693-705. doi: 10.1016/j.cell.2007.02.005

38. Chi P, Allis CD, Wang GG. Covalent Histone Modifications-Miswritten, Misinterpreted and Mis-Erased in Human Cancers. Nat Rev Cancer (2010) 10 (7):457-69. doi: 10.1038/nrc2876

39. Barth TK, Imhof A. Fast Signals and Slow Marks: The Dynamics of Histone Modifications. Trends Biochem Sci (2010) 35(11):618-26. doi: 10.1016/ j.tibs. 2010.05 .006

40. Iacobuzio-Donahue CA. Epigenetic Changes in Cancer. Annu Rev Pathol (2009) 4:229-49. doi: 10.1146/annurev.pathol.3.121806.151442

41. Struhl K. Histone Acetylation and Transcriptional Regulatory Mechanisms. Genes Dev (1998) 12(5):599-606. doi: 10.1101/gad.12.5.599

42. Puppin C, Passon N, Lavarone E, Di Loreto C, Frasca F, Vella V, et al. Levels of Histone Acetylation in Thyroid Tumors. Biochem Biophys Res Commun (2011) 411(4):679-83. doi: 10.1016/j.bbrc.2011.06.182

43. Kondo T, Nakazawa T, Ma D, Niu D, Mochizuki K, Kawasaki T, et al. Epigenetic Silencing of TTF-1/NKX2-1 Through DNA Hypermethylation and Histone H3 Modulation in Thyroid Carcinomas. Lab Invest (2009) 89(7):7919. doi: 10.1038/labinvest.2009.50

44. Lewis BP, Burge CB, Bartel DP. Conserved Seed Pairing, Often Flanked by Adenosines, Indicates That Thousands of Human Genes are MicroRNA Targets. Cell (2005) 120(1):15-20. doi: 10.1016/j.cell.2004.12.035

45. Lu J, Getz G, Miska EA, Alvarez-Saavedra E, Lamb J, Peck D, et al. MicroRNA Expression Profiles Classify Human Cancers. Nature (2005) 435(7043):834-8. doi: $10.1038 /$ nature03702
46. Marcucci G, Radmacher MD, Maharry K, Mrozek K, Ruppert AS, Paschka P, et al. MicroRNA Expression in Cytogenetically Normal Acute Myeloid Leukemia. N Engl J Med (2008) 358(18):1919-28. doi: 10.1056/ NEJMoa074256

47. Esquela-Kerscher A, Slack FJ. Oncomirs - microRNAs With a Role in Cancer. Nat Rev Cancer (2006) 6(4):259-69. doi: 10.1038/nrc1840

48. Li X, Abdel-Mageed AB, Mondal D, Kandil E. MicroRNA Expression Profiles in Differentiated Thyroid Cancer, a Review. Int J Clin Exp Med (2013) 6 (1):74-80.

49. Hung $\mathrm{CH}$, Chiu YC, Chen $\mathrm{CH}, \mathrm{Hu}$ TH. MicroRNAs in Hepatocellular Carcinoma: Carcinogenesis, Progression, and Therapeutic Target. BioMed Res Int (2014) 2014:486407. doi: 10.1155/2014/486407

50. de la Chapelle A, Jazdzewski K. MicroRNAs in Thyroid Cancer. J Clin Endocrinol Metab (2011) 96(11):3326-36. doi: 10.1210/jc.2011-1004

51. Nana-Sinkam SP, Croce CM. MicroRNA Regulation of Tumorsigenesis, Cancer Progression and Interpatient Heterogeneity: Towards Clinical Use. Genome Biol (2014) 15(9):445. doi: 10.1186/s13059-014-0445-8

52. Nikiforova MN, Tseng GC, Steward D, Diorio D, Nikiforov YE. MicroRNA Expression Profiling of Thyroid Tumors: Biological Significance and Diagnostic Utility. J Clin Endocrinol Metab (2008) 93(5):1600-8. doi: 10.1210/jc.2007-2696

53. Máximo V, Lima J, Prazeres H, Soares P, Sobrinho-Simões M. The Biology and the Genetics of Hürthle Cell Tumors of the Thyroid. Endoc Relat Cancer (2012) 19: (4):R131. doi: 10.1530/ERC-11-0354

54. Vriens MR, Weng J, Suh I, Huynh N, Guerrero MA, Shen WT, et al. MicroRNA Expression Profiling is a Potential Diagnostic Tool for Thyroid Cancer. Cancer (2012) 118(13):3426-32. doi: 10.1002/cncr.26587

55. Dettmer MS, Perren A, Moch H, Komminoth P, Nikiforov YE, Nikiforova MN. MicroRNA Profile of Poorly Differentiated Thyroid Carcinomas: New Diagnostic and Prognostic Insights. J Mol Endocrinol (2014) 52(2):181-9. doi: 10.1530/JME-13-0266

56. Petric R, Gazic B, Goricar K, Dolzan V, Dzodic R, Besic N. Expression of miRNA and Occurrence of Distant Metastases in Patients With Hurthle Cell Carcinoma. Int J Endocrinol (2016) 2016:8945247. doi: 10.1155/2016/ 8945247

57. Covach A, Patel S, Hardin H, Lloyd RV. Phosphorylated Mechanistic Target of Rapamycin (p-mTOR) and Noncoding Rna Expression in Follicular and Hurthle Cell Thyroid Neoplasm. Endocr Pathol (2017) 28(3):207-12. doi: 10.1007/s12022-017-9490-7

58. Jacques C, Guillotin D, Fontaine JF, Franc B, Mirebeau-Prunier D, Fleury A, et al. DNA Microarray and miRNA Analyses Reinforce the Classification of Follicular Thyroid Tumors. J Clin Endocrinol Metab (2013) 98(5):E981-9. doi: 10.1210/jc.2012-4006

59. Haigh PI, Urbach DR. The Treatment and Prognosis of Hurthle Cell Follicular Thyroid Carcinoma Compared With its non-Hurthle Cell Counterpart. Surgery (2005) 138(6):1152-7. doi: 10.1016/j.surg.2005.08.034

60. Grani G, Lamartina L, Durante C, Filetti S, Cooper DS. Follicular Thyroid Cancer and Hürthle Cell Carcinoma: Challenges in Diagnosis, Treatment, and Clinical Management. Lancet Diabetes Endocrinol (2018) 6(6):500-14. doi: 10.1016/S2213-8587(17)30325-X

61. (2019). Available at: http://www.nccn.org/professionals/physician_gls/pdf/ thyroid.pdf.

62. Haugen BR, Alexander EK, Bible KC, Doherty GM, Mandel SJ, Nikiforov YE, et al. 2015 American Thyroid Association Management Guidelines for Adult Patients With Thyroid Nodules and Differentiated Thyroid Cancer: The American Thyroid Association Guidelines Task Force on Thyroid Nodules and Differentiated Thyroid Cancer. Thyroid (2016) 26(1):1-133. doi: 10.1089/ thy. 2015.0020

63. Schlumberger M, Tahara M, Wirth LJ, Robinson B, Brose MS, Elisei R, et al. Lenvatinib Versus Placebo in Radioiodine-Refractory Thyroid Cancer. N Engl J Med (2015) 372(7):621-30. doi: 10.1056/NEJMoa1406470

64. Brose MS, Frenette CT, Keefe SM, Stein SM. Management of SorafenibRelated Adverse Events: A Clinician's Perspective. Semin Oncol (2014) 41 Suppl 2:S1-S16. doi: 10.1053/j.seminoncol.2014.01.001

65. Murakami T, Li X, Gong J, Bhatia U, Traganos F, Darzynkiewicz Z. Induction of Apoptosis by 5-Azacytidine: Drug Concentration-Dependent Differences in Cell Cycle Specificity. Cancer Res (1995) 55(14):3093-8. 
66. Yang X, Lay F, Han H, Jones PA. Targeting DNA Methylation for Epigenetic Therapy. Trends Pharmacol Sci (2010) 31(11):536-46. doi: 10.1016/ j.tips.2010.08.001

67. Provenzano MJ, Fitzgerald MP, Krager K, Domann FE. Increased Iodine Uptake in Thyroid Carcinoma After Treatment With Sodium Butyrate and Decitabine (5-Aza-Dc). Otolaryngol Head Neck Surg (2007) 137(5):722-8. doi: 10.1016/j.otohns.2007.07.030

68. Venkataraman GM, Yatin M, Marcinek R, Ain KB. Restoration of Iodide Uptake in Dedifferentiated Thyroid Carcinoma: Relationship to Human $\mathrm{Na}+/ \mathrm{I}-$ symporter Gene Methylation Status. J Clin Endocrinol Metab (1999) 84(7):2449-57. doi: 10.1210/jc.84.7.2449

69. Suzuki H, Gabrielson E, Chen W, Anbazhagan R, van Engeland M, Weijenberg MP, et al. A Genomic Screen for Genes Upregulated by Demethylation and Histone Deacetylase Inhibition in Human Colorectal Cancer. Nat Genet (2002) 31(2):141-9. doi: 10.1038/ng892

70. Miasaki FY, Vivaldi A, Ciampi R, Agate L, Collecchi P, Capodanno A, et al. Retinoic Acid Receptor Beta2 Re-Expression and Growth Inhibition in Thyroid Carcinoma Cell Lines After 5-Aza-2'-Deoxycytidine Treatment. J Endocrinol Invest (2008) 31(8):724-30. doi: 10.1007/BF03346422

71. West AC, Johnstone RW. New and Emerging HDAC Inhibitors for Cancer Treatment. J Clin Invest (2014) 124(1):30-9. doi: 10.1172/JCI69738

72. Greenberg VL, Williams JM, Cogswell JP, Mendenhall M, Zimmer SG. Histone Deacetylase Inhibitors Promote Apoptosis and Differential Cell Cycle Arrest in Anaplastic Thyroid Cancer Cells. Thyroid (2001) 11(4):31525. doi: $10.1089 / 10507250152039046$

73. Imanishi $R$, Ohtsuru $A$, Iwamatsu $M$, Iioka $T$, Namba $H$, Seto $S$, et al. A Histone Deacetylase Inhibitor Enhances Killing of Undifferentiated Thyroid Carcinoma Cells by p53 Gene Therapy. J Clin Endocrinol Metab (2002) 87 (10):4821-4. doi: 10.1210/jc.2002-020877

74. Kitazono M, Bates S, Fok P, Fojo T, Blagosklonny MV. The Histone Deacetylase Inhibitor FR901228 (Desipeptide) Restores Expression and Function of Pseudo-Null P53. Cancer Biol Ther (2002) 1(6):665-8. doi: $10.4161 /$ cbt. 317

75. Mitsiades CS, Poulaki V, McMullan C, Negri J, Fanourakis G, Goudopoulou A, et al. Novel Histone Deacetylase Inhibitors in the Treatment of Thyroid Cancer. Clin Cancer Res (2005) 11(10):3958-65. doi: 10.1158/10780432.CCR-03-0776

76. Kitazono M, Robey R, Zhan Z, Sarlis NJ, Skarulis MC, Aikou T, et al. Low Concentrations of the Histone Deacetylase Inhibitor, Depsipeptide (FR901228), Increase Expression of the $\mathrm{Na}(+) / \mathrm{I}(-)$ Symporter and Iodine Accumulation in Poorly Differentiated Thyroid Carcinoma Cells. J Clin Endocrinol Metab (2001) 86(7):3430-5. doi: 10.1210/jcem.86.7.7621

77. Furuya F, Shimura H, Suzuki H, Taki K, Ohta K, Haraguchi K, et al. Histone Deacetylase Inhibitors Restore Radioiodide Uptake and Retention in Poorly Differentiated and Anaplastic Thyroid Cancer Cells by Expression of the Sodium/Iodide Symporter Thyroperoxidase and Thyroglobulin. Endocrinology (2004) 145(6):2865-75. doi: 10.1210/en.2003-1258

78. D'Agostino M, Sponziello M, Puppin C, Celano M, Maggisano V, Baldan F, et al. Different Expression of TSH Receptor and NIS Genes in Thyroid Cancer: Role of Epigenetics. J Mol Endocrinol (2014) 52(2):121-31. doi: 10.1530/JME13-0160
79. Wachter S, Damanakis AI, Elxnat M, Roth S, Wunderlich A, Verburg FA, et al. Epigenetic Modifications in Thyroid Cancer Cells Restore NIS and Radio-Iodine Uptake and Promote Cell Death. J Clin Med (2018) 7(4):61. doi: $10.3390 / \mathrm{jcm} 7040061$

80. Damanakis AI, Eckhardt S, Wunderlich A, Roth S, Wissniowski TT, Bartsch DK, et al. MicroRNAs Let7 Expression in Thyroid Cancer: Correlation With Their Deputed Targets HMGA2 and SLC5A5. J Cancer Res Clin Oncol (2016) 142(6):1213-20. doi: 10.1007/s00432-016-2138-z

81. Raveh E, Matouk IJ, Gilon M, Hochberg A. The H19 Long non-Coding RNA in Cancer Initiation, Progression and Metastasis - a Proposed Unifying Theory. Mol Cancer (2015) 14:184. doi: 10.1186/s12943-015-0458-2

82. Wang P, Liu G, Xu W, Liu H, Bu Q, Sun D. Long Noncoding Rna H19 Inhibits Cell Viability, Migration, and Invasion Via Downregulation of IRS-1 in Thyroid Cancer Cells. Technol Cancer Res Treat (2017) 16(6):1102-12. doi: $10.1177 / 1533034617733904$

83. Woyach JA, Kloos RT, Ringel MD, Arbogast D, Collamore M, Zwiebel JA, et al. Lack of Therapeutic Effect of the Histone Deacetylase Inhibitor Vorinostat in Patients With Metastatic Radioiodine-Refractory Thyroid Carcinoma. J Clin Endocrinol Metab (2009) 94(1):164-70. doi: 10.1210/ jc.2008-1631

84. Sherman EJ, Su YB, Lyall A, Schöder H, Fury MG, Ghossein RA, et al. Evaluation of Romidepsin for Clinical Activity and Radioactive Iodine Reuptake in Radioactive Iodine-Refractory Thyroid Carcinoma. Thyroid: Off J Am Thyroid Assoc (2013) 23(5):593-9. doi: 10.1089/thy.2012.0393

85. Catalano MG, Pugliese M, Gargantini E, Grange C, Bussolati B, Asioli S, et al. Cytotoxic Activity of the Histone Deacetylase Inhibitor Panobinostat (LBH589) in Anaplastic Thyroid Cancer In Vitro and In Vivo. Int J Cancer (2012) 130(3):694-704. doi: 10.1002/ijc.26057

86. Duenas-Gonzalez A, Candelaria M, Perez-Plascencia C, Perez-Cardenas E, de la Cruz-Hernandez E, Herrera LA. Valproic Acid as Epigenetic Cancer Drug: Preclinical, Clinical and Transcriptional Effects on Solid Tumors. Cancer Treat Rev (2008) 34(3):206-22. doi: 10.1016/j.ctrv.2007.11.003

87. Nilubol N, Merkel R, Yang L, Patel D, Reynolds JC, Sadowski SM, et al. A Phase II Trial of Valproic Acid in Patients With Advanced, RadioiodineResistant Thyroid Cancers of Follicular Cell Origin. Clin Endocrinol (Oxf) (2017) 86(1):128-33. doi: 10.1111/cen.13154

88. Xie CH, Naito A, Mizumachi T, Evans TT, Douglas MG, Cooney CA, et al. Mitochondrial Regulation of Cancer Associated Nuclear DNA Methylation. Biochem Biophys Res Commun (2007) 364(3):656-61. doi: 10.1016/ j.bbrc.2007.10.047

Conflict of Interest: The authors declare that the research was conducted in the absence of any commercial or financial relationships that could be construed as a potential conflict of interest.

Copyright (๑) 2021 Canberk, Lima, Pinto, Soares and Máximo. This is an open-access article distributed under the terms of the Creative Commons Attribution License (CC BY). The use, distribution or reproduction in other forums is permitted, provided the original author(s) and the copyright owner(s) are credited and that the original publication in this journal is cited, in accordance with accepted academic practice. No use, distribution or reproduction is permitted which does not comply with these terms. 